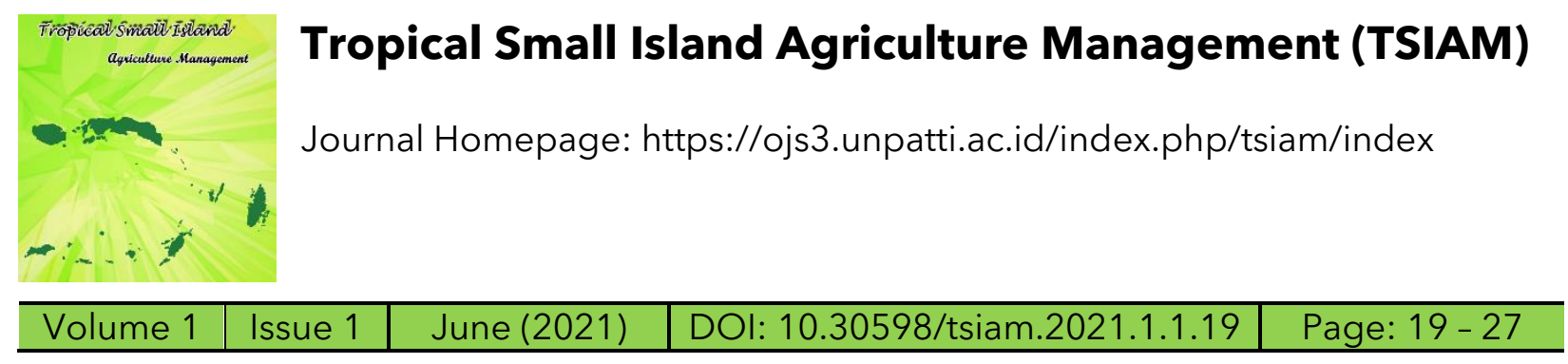

\title{
The Role Of Customary Institutions In Natural Resource Management In Kailolo, Haruku Island
}

\author{
Marthina Tjoa ${ }^{1}$, Mersiana Sahureka $^{2 \star}$, Arfandy Reyaan ${ }^{3}$ \\ 1.,2 Department of Forestry, Faculty of Agriculture, Pattimura University, Indonesia \\ ${ }^{3}$ Student of Department of Forestry, Faculty of Agriculture, Pattimura University, Indonesia
}

*Email Corresponding Author: mersisahureka@gmail.com

\section{ARTICLEINFO}

Keywords : Sasi, Social, Kewang, Natural resources

Received : 14 February 2021

Revised : 24 May 2021

Accepted : 29 June 2021

\begin{abstract}
A B S T R A C T
This study examines the role of the sasi institution in negeri Kailolo with the aim of knowing the form of sasi application and the role of the sasi institution in managing natural resources. The research approach used is descriptive qualitative. Data collection was carried out by interviewing community and traditional leaders as key informants. The results showed that a local institution that has legal values and contains norms and rules relating to ways, habits, behavior and customs that contain elements of ethics and norms is Sasi. The implementation of sasi is controlled by the kewang institution. The process of managing sasi by the kewang and the community together is able to carry out functions and responsibilities proportionally. Public compliance with the rules of sasi and the sasi controlling institution (kewang) is able to carry out its control function properly.
\end{abstract}

\section{Introduction}

Local wisdom is positive human behaviour in dealing with nature and the surrounding environment that can be sourced from religious values, customs, ancestral advice, or local culture built naturally in a community to adapt to the surrounding environment (Ohorella, et al. 2011; Soselisa 2019; Tehupeiory 2021). This behaviour develops into a culture in an area and will develop from generation to generation. In general, local culture or regional culture is interpreted as a culture that develops in an area, whose elements are culture and ethnic groups living in that area (Aminudin 2013; Rosita et al. 2017). 
The regulation of forest and natural resource management in Maluku is known as sasimanagement. The sasi system is unique in its implementation based on customary law in Maluku. The role of sasi allows natural resources to continue to grow and develop. In other words, biological and vegetable natural resources need to be conserved within a certain period to restore growth and development in order to achieve satisfactory results (Etlegar 2013; Haulussy et al. 2020; Sahetapy 2018).

Institutionalization in the management of the natural resources of negeri Kailolo has been going on for a long time. It is a genetic legacy from the ancestors until now (Gaspersz and Saiya 2019; Marasabessy 2018). The sustainability of the application of sasi shows that the role of sasi is vital enough to be preserved. Institutions related to the rights of others, the privileges granted, and the responsibilities they carry out. Institutions can also be interpreted as instruments that regulate the relationship of people or community groups through rights and obligations concerning resource utilization. Institutions have an essential role in society to reduce uncertainty by establishing a stable structure for human relations. Institutions play a role for individuals to make decisions in carrying out their activities (Patriana et al. 2016; Sangadji 2019).

The purpose of sasi is to maintain the values or norms in maintaining the natural resources today. The application of sasi in the negeri of Kailolo, still being carried out today, is sasimaleo (Eulopia Wallace). In addition, a lot of forest sasi is also carried out (Marasabessy 2018; Simanjuntak et al. 2020). The implementation of sasi in the negeri of Kailolo is supervised by the sasi institution, namely overseeing the process of implementing sasi to close the sasi and open the sasi. Based on this background, research was conducted with the title: The role of sasi institutions in natural resource management. This study aimed to 1). Explain the form of application of sasi in regulating natural resources in the negeri Kailolo. 2) Assess the role of sasi institutions in managing natural resources in the negeri Kailolo.

\section{Materials and Methods}

\section{Materials}

The research location was in negeri Kailolo, Haruku Island Subdistrict, Central Maluku Regency. Negeri Kailolo was chosen because it still applies sasi rules in natural resource management. The study was conducted in February 2019. The object of the study was the Indigenous Peoples of the negeri Kailolo, who carried out the institutional role of sasi in natural resource management. 


\section{Methods}

The method used in this study was a qualitative method using survey, observation, and interview methods. Data collection used purposive sampling by determining 20 respondents consisting of 10 heads of families and ten key informants consisting of negeri and community leaders. They are considered the most knowledgeable about implementing sasi and their role in natural resource management. The elected public figures include the king, secretary, religious leader, saniri, kewang, members of the kewang, head of government, and community affairs in the negeri Kailolo. Sources of data needed in this study were primary data, which included social data, community culture, and application of sasiand the role of sasi in natural resource management. Then, secondary data was supporting data obtained from various literature, journals, and critical notes related to sasi institutions and their role in natural resource management. Data analysis was carried out in a qualitative descriptive manner to obtain an overview of each research objective.

The data obtained from interviews, secondary collection, and observation were classified according to the theme of the problem study then analysis was carried out to obtain a conclusion. Analysis of the role of sasi institutions was carried out to determine the role of traditional institutions in regulating the control and utilization of natural resources. The role of sasi institutional rules was determined based on people who believe, understand and obey the sasirules, in general rules and special rules enforced by sasi institutions. A person's adherence to a rule can be weakened or strengthened by someone else's adherence to the rule. Therefore, it is essential to review one's belief that others obey the rules (Suharjito and Saputro 2008). The determination of the role of sasi institutions is based on the following criteria is role of a rule that is enforced in the sasi institution is said to be high if the community never or rarely violates the sasi rule.

\section{Results and Discussion}

\section{Community Characteristics}

Education as an object and subject of development needs to be considered because education is the primary driver of development. The education level of respondents in negeri Kailolo is shown in Table 1 and 2. 
Table 1. Education Level of Respondents Kailolo

\begin{tabular}{lccc}
\hline Education & Society & Key Informants & Percentage \\
\hline Elementary School & 3 & 4 & $35 \%$ \\
Junior High School & 3 & 1 & $20 \%$ \\
Senior High School & 4 & 5 & $45 \%$ \\
Higher Education & & & \\
\hline
\end{tabular}

Table 2. Kailolo Livelihoods

\begin{tabular}{lccc}
\hline \multicolumn{1}{c}{ Livelihood } & Society & Key Informants & Percentage \\
\hline Farmer & 7 & 7 & $70 \%$ \\
Civil Servant & 2 & 1 & $15 \%$ \\
\hline Fisherman & & & $\%$ \\
Labour & 1 & 1 & $5 \%$ \\
Entrepreneur & 1 & $10 \%$ \\
\hline
\end{tabular}

Livelihood is a method used by a group of people to utilize natural resources to meet the needs of life in a particular area. However, most people are farmers. Some are civil servants, labourers, and entrepreneurs in Kailolo. Tables 1 and 2 show that generally, the education level of the respondents is high school graduates, and most of them work as farmers, which also affects the respondents' understanding in applying the rules and sanctions in the implementation of sasi.

\section{Soa}

Soa, or the eyes of the house in Maluku society, is referred to one of the houses where the clan or fam comes from. Domestic clans have certain nicknames or titles such as kapitang, priest, king, landlord, kewang, and marinyo. Therefore, the person usually performs the ritual representing the soa or the eyes of the house at traditional ceremonies. In the negeri Kailolo, there are six soa, which have different functions and positions in the negeri, namely the soa Tuanani, Nurlembe, Tuanaya, Ohorella, Putiiman and Mahu.

\section{Public Knowledge of Sasi}

Sasi has rules and procedures for implementation, utilization, maintenance, and supervision to maintain environmental balance and future generations can utilize natural resources. This customary law teaches that humans should preserve the survival of other humans and not use natural resources excessively, resulting in disruption of the balance of nature. Sasican have legal value because it has norms and rules relating to ways, habits, behaviour, and customs containing ethics and norms (Harkes 1999; Karepesina and Susilo 2013). According to the views or knowledge of the people of negeri Kailolo, sasi is an 
example of sustainable management and utilization of natural resources carried out by the community based on local knowledge passed down from generation to generation to maintain the availability of natural resources (Marasabessy 2018).

People in Kailolo have known about sasisince their ancestors, and its implementation is still ongoing because it is the commitment of the people of Kailolo negeri in protecting natural resources both around the forest and in the Maleo cape so that they are not disturbed or lost due to excessive exploitation activities in the progress of the times (Gaspersz and Saiya 2019).

\section{The Role of Negeri Institution in the Implementation of Sasi}

The Negeri government and the people of negeri Kailolo in principle support the application of sasi in resource management. It is the duty of financial institutions that the negeri government supports, including the king, secretary of negeri, saniri, government structures and the public in neger Kailolo to implement sasithrough auction activities. As long as the sasi is enforced, there are rarely any violations. Therefore, it can be said that the community is aware of the importance of sasi in natural resource management. The structure of the financial institution in the negeri of Kailola can be seen in Figure 1.

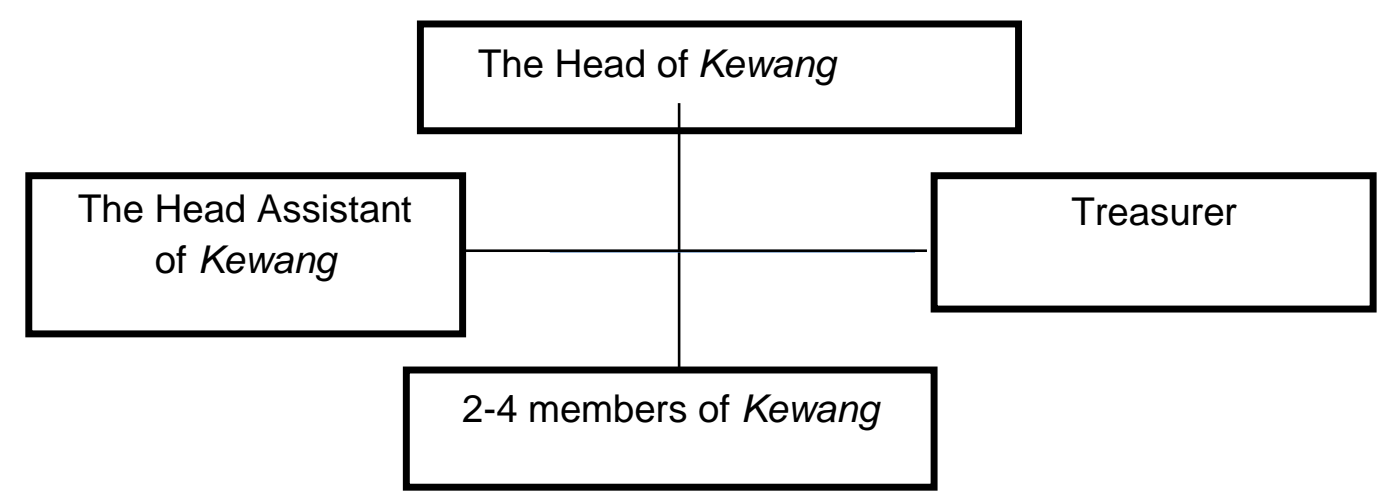

Figure 1. Structure of the financial institution in the negeri of Kailola

The duties of each kewang institution are as follows are (Marasabessy 2018; Ohorella, et al. 2011) :

1. The head of kewang is the person who has the policy in the structure. The head of the kewang is responsible for and controls the process of implementing the sasi. The head of kewang is usually the winner of the auction process to implement sasi in the negeri Kailolo. The government usually trusts the winning Kewang head to manage natural resources for a certain period until the next auction.

2. The head assistant of kewang, as an extension of the kewang head, assists the head of kewang in policy matters when the head of kewang is not in place. The head 
assistant of the kewang usually assists the process of implementing regulations or prohibitions on taking resources that are applied to the community in the sasi process and managing sasi together with other members.

3. A treasurer is a person who is trusted and appointed by the head of kewang to handle financial management issues properly to get maximum results.

4. Kewang members consist of 2 to 4 people who are tasked with maintaining and controlling the implementation of sasi, both related to the type and location of sasi so that there are no sasi violations such as theft. Kewang members work based on targets in order to be able to return the money that has been spent when winning sasi.

The Kewang Institution does not experience any problems in carrying out its duties even though the number of members is not large. The Kewang Institution divides the supervisory duties based on the location of the sasi. The management of sasi in negeri Kailolo is quite popular with auctions, so there is relatively no conflict from outside parties. This is because the people of the negeri Kailolo are aware of and understand the applicable customary law.

\section{Implementation of sasi in Kailolo}

Sasi is applied only to specific flora and fauna, while for other resources, it is allowed to be taken and utilized by the community (Nanlohy et al. 2019; Satria and Mony 2019). Sasi has rules and procedures for the implementation, utilization, maintenance, and supervision so that the balance of the environment is maintained and the next generation can utilize the natural resources in it. This customary law teaches that humans should maintain the continuity of other living things and not use natural resources excessively, which results in disruption of the natural balance. Sasican have legal value because it has norms and rules related to ways, habits, behaviour, and customs containing ethics and norms.

The dominant form of local wisdom is related to natural resource management, namely sasi (ban). It is a prohibition on taking/collecting/harvesting forest or marine products before time. Enforcement and implementation of sasiaim to maintain the quality and quantity of natural resources to remain preserved and sustainable. Natural resources in the negeri Kailolo are not much. However, the results of managed sasi have their uniqueness or attraction, namely the auction system. It means that the winner of the auction has the authority to manage sasi. The community usually holds an auction process at the negeri Kailolo hall. The auction activity is an annual activity for the people of the negeri Kailolo to gather at the negeriHall to convey suggestions and opinions at that moment. 
The sasimanagement method of the result of the resources is usually offered to the community in the negeri Kailolo.

The negeri government will offer the community the resource results, which will be managed for one or two years. Whoever makes the bid with the highest price will win the auction and has the right to manage the sasi for the time determined by the negeri. During the implementation of sasi, usually three times a year, the head of the kewang asks the Imam of the mosque to pray at the sasilocation so that more maleo birds and maleo eggs are protected and preserved by the people of the negeri of Kailolo. After praying, the Imam of the mosque sprinkled rice and fed the maleo. The maleo bird's egg sasi (Eulipoa Wallace) is located in Tanjong Maleo, and there are also four hatching locations, three locations where eggs can be taken while one location is usually left for eggs to hatch. The total area is 1,600 hectares. The results of the sasiare then sold to the people of Kailolo negeri and interested outsiders. The proceeds are usually used for development in the Kailolo negeri with $75 \%$ for the mosque, $15 \%$ for the negerigovernment and $10 \%$ for the winner of the sasiauction. However, there are also maleo laying eggs that are not taken to hatch and continue to breed. Meanwhile, sasialso prevails for other natural resources, namely forest sasifor coconut (Cocos nucifera) and nutmeg (Myristica fragrans), located in sasi petuanan Lalean forest and Hitapori forest.

Sasi is made based on community knowledge about the time or period when a resource can be harvested so that it does not interfere with the life cycle and the community gets good and maximum results. The position of sasi is more likely to be legal than traditional because using sasi is more likely to be legal than traditional because the purpose of using sasi is how people are wise in taking and managing results (Ruhulessin 2017; Satria and Mony 2019). In the negeri of Kailolo, closing and opening sasi is usually marked by tabaos carried out by marinyo to convey messages to the community by walking around the village while conveying messages by sounding a clapper. Sasi is usually done every year at the end of March. In carrying out sasi law, regulation is usually made for the people of the negeri so that it can bind the community not to violate these rules. In the negeri Kailolo, the sasi law has a deterrent level according to the violated act. The provisions and sanctions for sasi violations are as follows:

1. It is forbidden to take the results of sasi if it is closed

IDR. $7.500 / p c$

2. Cutting down trees

IDR. 5.000/tree

3. It is forbidden to take maleo eggs

IDR 5.000/grain

As for the forest sasi, it has the following provisions. The applicable forest sasi will be subject to the following sanctions: 
1. Coconut fruit

IDR 5.000/fruit

2. Nutmeg

IDR 5.000/fruit

3. Cutting Down

IDR 5.000/tree

Suppose kewang get people to violate the sasi, even small children or adults. In that case, they will be given sanctions in the form of fines following applicable regulations or mixed and advised according to the level of violation. The kewang did not found any problem in implementing sasi in negeri Kailolo because the kewang has divided tasks according to a location to control the implementation of sasiboth by the kewang and the negeri government.

\section{Conclusion}

The level of implementation of sasi in negeri Kailolo is relatively effective and efficient. The form of sasi consists of forest sasi and Tanjung Maleo sasi. The application of sasi begins with an auction by the negeri government. The person who wins the auction has the right to run the sasi and act as the controller of the sasi. The implementation of sasi provides proportional income and profit sharing to the community and the negeri government, especially for the development of the negeri Kailolo. The role of the sasi institution as a controller (kewang) performs its function properly. This is indicated by the community's compliance with the sasi rules.

\section{References}

Aminudin. 2013. Menjaga Lingkungan Dengan Kearifan Lokal. Bandung: Titian IImu.

Etlegar, Dahlan. 2013. "Peran Lembaga Adat Sasi Dalam Pengelolaan Sumberdaya Dusun Di Negeri Allang Kecamatan Leihitu Barat, Kabupaten Maluku Tengah."

Gaspersz, Elisa J., and Halvina G. Saiya. 2019. "PEMETAAN KEARIFAN LOKAL BUDAYA SASI DI NEGERI HARUKU DAN NEGERI KAILOLO, PULAU HARUKU, KABUPATEN MALUKU TENGAH." Seminar Nasional Geomatika 3.

Harkes, Ingvild. 1999. "An Institutional Analysis of Sasi Laut, a Fisheries Management System in Indonesia." Proceedings of International Workshop on Fisheries Comanagement.

Haulussy, Rais Rahman, Najamuddin, Rabihatun Idris, and Andi Dody May Putra Agustang. 2020. "The Sustainability of the Sasi Lola Tradition and Customary Law (Case Study in Masawoy Maluku, Indonesia)." International Journal of Scientific and Technology Research 9(2).

Karepesina, Sakina Safarina, and Edi Susilo. 2013. "Kabupaten Maluku Tengah Existence of 
Customary Law in Protecting the Conservation of Sasiin Haruku Central." Jurnal ESCOFim 1(1): 25-41.

Marasabessy, Husain. 2018. "KEARIFAN LOKAL DALAM PENGELOLAAN HUTAN (STUDI KASUS KELEMBAGAAN SASI HUTAN DI DESA KAILOLO KECAMATAN PULAU HARUKU KABUPATEN MALUKU TENGAH)." JURNAL HUTAN PULAU-PULAU KECIL 2(1).

Nanlohy, H., W. Talakua, L. M. Soukotta, and E. G. Talakua. 2019. "Factors Affecting Implementation of Sasi in the Management of Mangrove Ecosystem at Rutong and Leahari Village, South Leitimur Sub-District, Ambon City, Indonesia." In IOP Conference Series: Earth and Environmental Science,.

Ohorella, Syarif, Didik Suharjito, and lin Ichwandi. 2011. "Efektivitas Kelembagaan Lokal Dalam Pengelolaan Sumber Daya Hutan Pada Masyarakat Rumahkay Di Seram Bagian Barat, Maluku." Jurnal Manajemen Hutan Tropika XVII(2).

Patriana, Ratna, Soeryo Adiwibowo, Rilus A. Kinseng, and Arif Satria. 2016. "PERUBAHAN KELEMBAGAAN DALAM PENGELOLAAN SUMBERDAYA LAUT TRADISIONAL (KASUS KELEMBAGAAN SASI DI KAIMANA)." Sodality: Jurnal Sosiologi Pedesaan $4(3)$.

Rosita, Imran Rachman, Andi Sahri Alam. 2017. "Kearifan Masyarakat Lokal Suku Lauje Dalam Pengelolaan Hutan Di Desa Bambasiang Kecamata Palasa Kabupaten Parigi Moutong." Warta Rimba 5(1): 80-86.

Ruhulessin, H. 2017. "PERANAN KORPS KEWANG DALAM MELESTARIKAN LINGKUNGAN DI KEPULAUAN LEASE." Jurnal Hukum \& Pembangunan 15(4).

Sahetapy, Meilane. 2018. "POTENSI KEARIFAN LOKAL SASI BIODIVERSITY LAUT DI MALUKU DALAM PENGUATAN PEMBELAJARAN SAINS." Prosiding Seminar Nasional Pendidikan Biologi.

Sangadji Muspida, Maryam. 2019. "Model Ekonomi Bersama Melalui Budaya Sasi Kontrak Dan Sasi Negeri Di Kepulauan Maluku." Media Trend 14(1).

Satria, Arif, and Ahmad Mony. 2019. "Dinamika Praktek Sasi Laut Di Tengah Transformasi Ekonomi Dan Politik Lokal." Jurnal Sosiologi Pedesaan 7(2).

Simanjuntak, Radios et al. 2020. "Short Communication: Egg Harvesting and Local Conservation of Moluccan Scrubfowl (Eulipoa Wallacei) in the Maluku Islands, Indonesia." Biodiversitas 21(7).

Soselisa, H. L. 2019. "Sasi Lompa: A Critical Review of the Contribution of Local Practices to Sustainable Marine Resource Management in Central Maluku, Indonesia." In IOP Conference Series: Earth and Environmental Science,.

Suharjito, Didik;, and Gunanto Eko Saputro. 2008. "MODAL SOSIAL DALAM PENGELOLAAN SUMBERDAYA HUTAN PADA MASYARAKAT KASEPUHAN, BANTEN KIDUL." E-Jurnal Penelitian Sosial dan Ekonomi kehutanan 5(2).

Tehupeiory, Aarce. 2021. "SASI - BASED PROTECTION FOREST STRATEGY IN MALUKU (AMBON)." International Journal of Research -GRANTHAALAYAH 9(3). 